\title{
Effects of diflubenzuron on associated insect fauna with Anopheles (Diptera: Culicidae) in laboratory, partial-field, and field conditions in the Central Amazon
}

\author{
FRANCISCO A.S. FERREIRA, ADRIANO N. ARCOS, NATALIELLI S.G. MAIA, RAQUEL \\ T.M. SAMPAIO, FÁBIO M. COSTA, ILÉA B. RODRIGUES \& WANDERLI P. TADEI
}

\begin{abstract}
This study aimed to analyze the possible effects of diflubenzuron on the associated insect fauna under laboratory, semi-field and field conditions. Laboratory bioassays were performed in aquariums with mortality readings (\%) every $24 \mathrm{~h}$ until $96 \mathrm{~h}$, and in semi-fields, insects were kept in basins with readings every $24 \mathrm{~h}$ for up to 12 days, in triplicates and a control. In the field experiment, a collection was performed before the application of diflubenzuron in ten brick factory pits $\left(25 \mathrm{~m}^{2}\right)$ and 15 post-application. The values of $\mathrm{LC}_{50}$ and $\mathrm{LC}_{90}$ for Chironomus were $2.77 \times 10-3 \mathrm{~g} / \mathrm{L}$ and $0.86 \mathrm{~g} / \mathrm{L}$, respectively, and for Buenoa, they were $0.019 \mathrm{~g} / \mathrm{L}$ and $0.92 \mathrm{~g} / \mathrm{L}$, a strong relationship was observed between mortality and exposure time $\left(r^{2}>0.8\right)$ in all concentrations used. In semi-field, similar mean values of emergency inhibition were observed, except for Euthyplociidae, which was more sensitive. There was no significant difference between the data of richness and diversity of aquatic insects in the field experiment, considering an interval of 15 days ( $p=0.32$ ). Finally, the data suggest that diflubenzuron may have a negative effect on the associated insect fauna, but in the field experiment the environmental conditions of Anopheles breeding sites may have affected its efficiency.
\end{abstract}

Key words: Amazonia, Chironomus sp., Chitin, Anopheles.

\section{INTRODUCTION}

Insects integrate the aquatic macroinvertebrates community, as they play important roles in nutrient cycling within an ecosystem, by converting plant matter into animal tissue, and are energy sources for other trophic levels (Merritt et al. 2008, Albertoni \& Palma-Silva 2010). In addition, some insect groups such as Ephemeroptera, Plecoptera, and Trichoptera serve as bioindicators of environmental impacts (Al-Shami et al. 2013, 2014, Wandscheer et al. 2017).
The immature forms of Anopheles darlingi Root, 1926 which are the principal vectors of Malaria in Brazil, develop in fresh water and their population density peaks of winged forms is related to the annual rain cycle, as the availability of breeding grounds increases. Such breeding grounds are classified as natural or artificial in the Amazonian environment, and house several other insect groups, which are referred to as the associated insect fauna during mosquito control campaigns (Ferreira et al. 2015, Tadei et al. 2017).

Controlling anopheline larvae is essential to decrease the density of adult anophelines 
and, consequently, the number of Malaria cases. Therefore, control strategies, which usually use organophosphates, carbamates, and pyrethroids with neurotoxic action, are necessary (Braga \& Valle 2007). However, such compounds are responsible for environmental damage and the development of resistant mosquito populations (Bellinato et al. 2016, Hemingway et al. 2004). Furthermore, these compounds present high residual power, remaining in environments for long periods of time, and wide action spectrum, reaching other organisms, including vertebrate, in aquatic environments (Wilke et al. 2009).

Currently, biological control is usually recommended for natural breeding sites, consisting of biotic agents that act on immature insect forms to reduce the density of disease vectors (Ferreira et al. 2015). In this context, the conservation of natural enemies that act as larvae predators and the entomopathogenic bacteria - Bacillus thuringiensis var. Israelis (Bti) and Lysinibacillus sphaericus - can potentially combat the immature forms of vector mosquitoes (Lobo et al. 2018, Rodrigues et al. 2013, Soaresda-Silva et al. 2015).

However, the use of chemical insecticides is indispensable for certain environmental situations and, in this context, growth regulators gain prominence (Martins \& Silva 2004). Such insecticides cause physiological and morphological modifications during insect development, in addition, they have low toxicity for vertebrates and are authorized by the World Health Organization (WHO) for drinking water (Lyra et al. 1998, WHO 2006, 2007).

The morphological modifications to insects are caused by the mode of action of these insecticides, which target the biosynthesis of chitin. In arthropods, chitin is essential for the formation of the exoskeleton, growth, and development of the individual (Merzendorfer \& Zimoch 2003). In addition, chitin is a fundamental constituent for the formation of the peritrophic matrix, making the interruption of biosynthesis an attractive target for the development of effective and safe insecticides, since mammals do not biosynthesize chitin (Cohen 2001, Merzendorfer 2006).

Diflubenzuron is an insect growth regulator and acts on Culicidae by interrupting larvae development, causing death during ecdysis, preventing the elimination of the old cuticle, or causing the new cuticle to no longer support the pressure exerted by the muscles, which can allow animals to survive for some time until death (Mulla 1979, Mulla \& Darwazeh 1975, 1979). In addition, diflubenzuron may also reduce adult emergence by interrupting the individual's life cycle during the transition between pupa and adult phases (Borges et al. 2012, Costa \& Tadei 2012, Mulla 1995).

In Brazil, this insecticide started to be used in 2009 and receives special attention in mosquito control programs where mosquitoes have become resistant to traditional insecticides such as Temephós ${ }^{\circledR}$ (Bellinato et al. 2016, Hemingway \& Ranson 2000). Severeal studies have proven the efficiency of diflubenzuron in the field and laboratory conditions on the most globally important mosquito genera: Aedes (Borges et al. 2012, Flacio et al. 2015, Machado et al. 2015, Rocha et al. 2015), Anopheles (Costa \& Tadei 2011, 2012, Zhu et al. 2007) and Culex (Msangi et al. 2011, Sadanandane et al. 2012, Zahran et al. 2013).

In the Amazon, the anophelines develop in water collections composed of river basins, permanent and semi-permanent lakes, environments classified as natural breeding sites (Forattini 2002). However, some species of anophelines are adapted to develop in anthropically altered environments, such as fish ponds and clay pits, classified as artificial breeding sites (Arcos et al. 2018). According to 
Ferreira et al. (2015), the associated insect fauna present in artificial breeding sites of the fish ponds type is composed of six orders and 23 families, among which stand out Chironomidae and Notonectidae.

Notonectids are small predators that inhabit several types of aquatic ecosystems and, in the Amazon, the genus Notonecta and Buenoa, can be found in standing water reservoirs with little or moderate amount of aquatic plants, typical characteristics of the artificial breeding sites of Anopheles darlingi (López Ruf et al. 2003). In addition to predatory aquatic insects, breeding sites have benthic insects represented by the orders Diptera (Chironomidae), Ephemeroptera and Trichoptera, which act to recycle nutrients and integrate the trophic chain into the aquatic environment, serving as food for fish, amphibians and birds. (Trivinho-Strixino \& Strixino 1995, Ayres-Peres et al. 2006).

Aquatic insects are among the most suitable organisms to estimate environmental impacts since they have abundant populations and are distributed in various microhabitats (Callisto \& Gonçalves 2005, Rosenberg \& Resh 1993). Benthic insects live in the sediment and tend to accumulate pesticide residues, making them potential indicators of environmental change (Martins et al. 2014).

Such changes in the environment often occur due to the implementation of control strategies. The control of mosquito vectors involves strategies for reducing the density of larvae in endemic regions where insecticide chemicals are applied in the environment and threaten other coexisting aquatic organisms.

In view of the importance of the associated insect fauna for the aquatic ecosystem, it is necessary that studies be performed to investigate the effects of insecticides frequently used for the control of Culicidae in the environment. The possible impacts on the associated insect fauna with Anopheles in aquatic ecosystems can compromise the survival of higher trophic levels, since insects make up the base of the food chain in this type of environment. In addition, some taxa are known to be predators of Culicidae larvae, promoting a natural control of mosquito vectors, such as the Notonectidae of the genus Buenoa and Notonecta, as well as immature dragonflies and water bugs.

Diflubenzuron is still used in several control campaigns and no studies have evaluated its effects on the associated insect fauna with Anopheles in Brazil. Thus, this study aims to evaluate the effects of diflubenzuron on members of the aquatic associated insect fauna with Anopheles in laboratory, partial-field, and artificial breeding site conditions in the Amazon region.

\section{MATERIALS AND METHODS}

\section{Sampling of insects}

Insects were collected in breeding sites located in the peri-urban region of Manaus, Amazonas State, and were used in bioassays in the laboratory and partial-field conditions. The specimens were collected using aquatic entomological nets and sorted, for laboratory bioassays the following groups were selected: Buenoa (Hemiptera: Notonectidae) and Chironomus (Diptera: Chironomidae). The partial-field bioassays were carried out using the following groups: Chironomidae (Diptera), Hydropsychidae (Trichoptera), Notonectidae (Hemiptera) and Euthyplociidae (Ephemeroptera).

The field experiment occurred in artificial breeding sites of Anopheles, called brick factory pits, located at Km 5 of the AM 070 Highway, which links the municipality of Manaus to Manacapuru (AM). This region has a large number of potteries, which remove clay from the ground and form 
pits that become filled with water when the Rio Negro is full and serve as breeding sites for mosquitos and various aquatic insect groups.

To evaluate the possible effects in the field conditions we perform samplings before (preapplication) and after (post-application - 15 days) of diflubenzuron, using aquatic entomological nets for a period of 5 minutes. The sediment collected was stored in plastic bags for further screening and identification. Collected material was sifted and aquatic insects were collected and fixed in alcohol 70\% for identification using the appropriate dichotomous keys (Borror \& Delong 2011, McCafferty 1981).

\section{Larvicide used}

The larvicide diflubenzuron was weighed into $1 \mathrm{~g} / \mathrm{L}$ doses, using a precision balance, and stored in aluminum foil envelopes for transportation to the experiment site. The standard solution was prepared from $5 \mathrm{~g}$ of Dimilin ${ }^{\circledR}$ containing $1.250 \mathrm{mg}$ of diflubenzuron, which was diluted in $1 \mathrm{~L}$ of water from the commercial product (250g of DFB/ Kg of Dimilin $\left.{ }^{\circledR}\right)$. The insecticide was applied directly to the water, simulating the methods used in mosquito control campaigns, with no water renewal during the period of the experiment. In the field, the dose was calculated according to the size of the breeding site recommended by the manufacturer $(1 \mathrm{~g} / \mathrm{L})$.

\section{Laboratory bioassay}

Specimens of Chironomus (Insecta: Diptera) and Buenoa (Insecta: Notonectidae) were kept in aquariums $(15 \mathrm{~cm}$ height, $14 \mathrm{~cm}$ width, and $25 \mathrm{~cm}$ length) containing $1 \mathrm{~L}$ of water from the breeding site with an aeration system and at room temperature. After the selective bioassays, the following doses were used: $250 \mathrm{mg} / \mathrm{L}, 312.5 \mathrm{mg} / \mathrm{L}$, $750 \mathrm{mg} / \mathrm{L}$ for Chironomus and $250 \mathrm{mg} / \mathrm{L}, 750 \mathrm{mg} / \mathrm{L}$ and $1 \mathrm{~g} / \mathrm{L}$ for Buenoa. Readings were performed at intervals of $24,48,72$, and 96 hours after application, prepared in triplicate and a control. The criteria for bioassay evaluation is described by Dulmage et al. (1990), with modifications: mortality in the control group could not surpass $30 \%$ and the confidence interval was $95 \%$.

The assessment of diflubenzuron application in the laboratory on the associated insect fauna was determined from the mortality rate (\%), which were subject to regression analysis using the Biostat 5.0 software. This analysis was performed to verify the relationship between exposure time and mortality (\%) after the application of the larvicide. Lethal concentrations were obtained using the POLO PC program, generated from the readings of mortality rate (\%) obtained from the bioassays of each group tested (LeOra Software 1987).

\section{Partial-field bioassay}

The partial-field experiment was conducted by simulating field conditions in a forest fragment area on the campus of the Instituto Nacional de Pesquisas da Amazônia -INPA. Plastic basins ( $0.50 \mathrm{~m}$ diameter and $0.20 \mathrm{~m}$ height) with $20 \mathrm{~L}$ capacity were installed in a shaded area, near a stream and fish ponds. Just like in the laboratory, we carried out three treatments and a control for each taxa submitted to the bioassays.

Colonization was artificial by transporting insects and introducing them into the basins with water from the breeding sites. Basins were grouped together and protected in by canvas cover to prevent rain from entering and were individually protected using fabric to prevent natural colonization by other organisms.

In this experiment, we applied a $250 \mathrm{mg} / \mathrm{L}$ dose of diflubenzuron and the methods for evaluating the effects on aquatic insects were performed according to Mulla \& Darwazeh (1975), with some modifications: the effects on the tested insect families were analyzed through mortality rates (\%) up to the fifteenth day of 
bioassay and the emergence inhibition rate (IE $=100-\mathrm{T} / \mathrm{C} \times 100)$ was calculated. Where: IEemergence inhibition; T-emergence or survival in treatment; C-emergence or survival in control.

The relationship between exposure time and mortality (\%) of individuals subjected to bioassays in the partial-field was evaluated through regression analysis. To evaluate possible differences in response to the insects analyzed, the emergence inhibition data was submitted to ANOVA using the software Biostat v.5.0. Subsequently, to find groupings with differentiated responses, the data was subjected to a Tukey test $(p<0.05)$.

\section{Field application}

Ten brick factory pits, with approximately $25 \mathrm{~m}^{2}$, were selected for the in- field experiment (Figure 1). The larvicide was applied using the dosage recommend by the manufacturer $(250 \mathrm{mg} / \mathrm{L})$, with the help of Guarany ${ }^{\circledR}$ Atomizer at the breeding site borders. The evaluation consisted of samplings (readings) pre-application and 15 days post-application, considering ecological indices of relative abundance, richness and diversity of Shannon $\left(H^{\prime}\right)$ and functional trophic feeding groups.

We calculated relative abundance (\%), diversity, and richness of the associated insect fauna using the program Dives - Diversity of Species v.4.4.8 (Rodrigues 2018) and specimens were classified according to their functional trophic feeding groups as presented by Cummins (2016). We analyzed the effects of diflubenzuron on aquatic insect populations by comparing the average richness and diversity from the pre-application and post-application samples, using a T-test in the Biostat software v.5.0. The breeding sites used in the field bioassay were characterized and the limnological data of temperature, $\mathrm{pH}$, and electrical conductivity were obtained using a field $\mathrm{pH}$ meter and a conductivity meter (Orion pH 290A + and VWR “EC METER" 2052).

\section{RESULTS}

\section{Bioassays laboratory}

The mortality data (\%) of Chironomus indicated high susceptibility to diflubenzuron at doses $250 \mathrm{mg} / \mathrm{L}$ and $750 \mathrm{mg} / \mathrm{L}$, both resulting in more than $70 \%$ mortality in the $96 \mathrm{~h}$ interval. In addition, a strong relationship between exposure time and mortality $\left(r^{2}=0.8,0.9\right.$ and 0.9$)$ was observed considering all doses tested in the laboratory. We verified high susceptibility of Buenoa to diflubenzuron at doses of $750 \mathrm{mg} / \mathrm{L}$ and $1 \mathrm{~g} / \mathrm{L}$. The effect of diflubenzuron at the dose of $250 \mathrm{mg} / \mathrm{L}$ started $72 \mathrm{~h}$ after application and from $96 \mathrm{~h}$ more than half of the individuals submitted to the bioassay were eliminated. The doses $750 \mathrm{mg} / \mathrm{L}$ and $1 \mathrm{~g} / \mathrm{L}$ presented high mortality rates, starting soon after $24 \mathrm{~h}$ and continuing up to $96 \mathrm{~h}$. The peak activity of the larvicide on Buenoa occurred in the $96 \mathrm{~h}$ postdose interval and, at the highest dose, the mortality was $100 \%$ of the individuals submitted to the bioassay. The regression analysis based on the results found for Buenoa, showed that there is a strong relation between exposure time and mortality rate $\left(r^{2}=0.8,0.9\right.$ and 0.8$)$ at all doses analyzed in the $96 \mathrm{~h}$ interval (Table I).

The peak activity of diflubenzuron was greater in $96 \mathrm{~h}$ post-application for both groups and the mortality rate (\%) did not exceed 30\% control group. According to the mortality (\%) data found for both groups, it was possible to obtain lethal concentrations, where for Buenoa the value of $\mathrm{LC}_{50}$ obtained was $2.77 \times 10^{-3} \mathrm{~g} / \mathrm{L}$ and $\mathrm{LC}_{90}$ was $0.86 \mathrm{~g} / \mathrm{L}$, whereas for Chironomus the $\mathrm{LC}_{50}$ was $0.019 \mathrm{~g} / \mathrm{L}$ and the $\mathrm{LC}_{90}$ was $0.92 \mathrm{~g} / \mathrm{L}$. Both values are below the manufacturer's recommended dose for mosquito control, which is $1 \mathrm{~g} / \mathrm{L}$ (Table $\mathrm{l})$. 


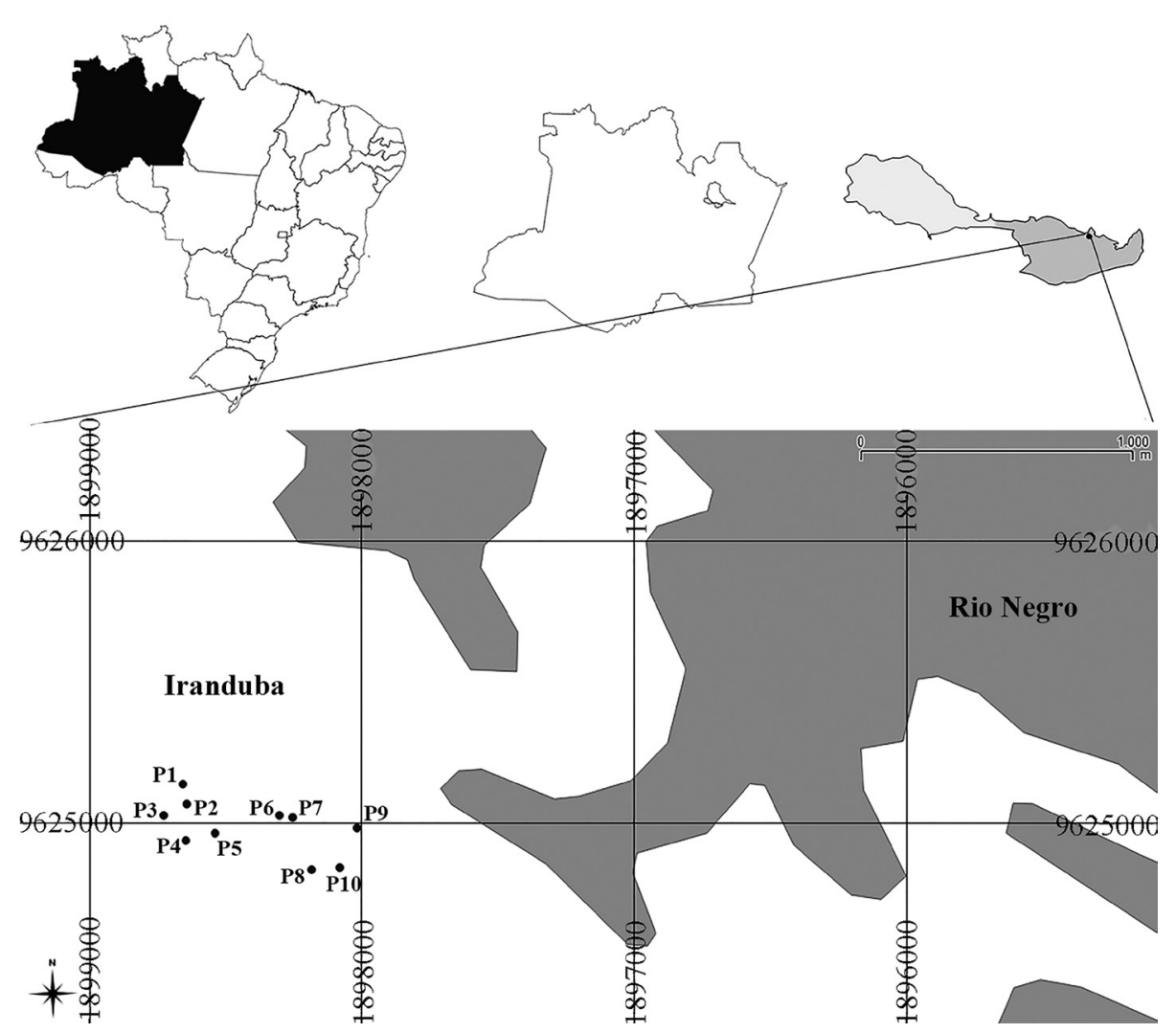

Figure 1. Clay pits (P1 to P10) used in the field experiment with application of diflubenzuron, in the municipality of Iranduba, Metropolitan Region of Manaus Amazonas, Brazil.

Table I. Mortality rate (\%) of the groups submitted to laboratory and partial-field bioassays, with readings performed up to 96 hours after application (dose - mg/L; CL - g/L).

\begin{tabular}{|c|c|c|c|c|c|c|c|c|c|}
\hline \multicolumn{10}{|c|}{ Mortality rate (\%) - Laboratory bioassay } \\
\hline Taxon & $\mathbf{n}$ & Dose (mg/L) & 24 & 48 & 72 & 96 & $\mathbf{r}^{2}$ & $\mathrm{LC}_{50}$ & $\mathrm{LC}_{90}$ \\
\hline \multirow{3}{*}{ Chironomus } & 60 & 250 & 13 & 29 & 53 & 76 & 0.8 & \multirow{3}{*}{0.019} & \multirow[t]{3}{*}{0.92} \\
\hline & 60 & 312.5 & 0 & 5.5 & 16.5 & 32.5 & 0.9 & & \\
\hline & 60 & 750 & 4 & 16.5 & 35.5 & 73 & 0.9 & & \\
\hline \multirow{2}{*}{ Buenoa } & 60 & 750 & 5 & 38 & 76 & 95 & 0.9 & \multirow{2}{*}{$2.77 \times 10^{-3}$} & \multirow[t]{2}{*}{0.86} \\
\hline & 60 & 1000 & 4 & 12 & 43 & 100 & 0.8 & & \\
\hline \multicolumn{10}{|c|}{ Mortality rate (\%) - Partial-fields bioassay } \\
\hline Taxon & $\mathbf{n}$ & 24 & 48 & 72 & 96 & $r^{2}$ & E.I(\%)* & $\pm S D$ & p \\
\hline Chironomidae & 60 & 11 & 27 & 48 & 76 & 0.9 & $2.6 b$ & 3.7 & 0.751 \\
\hline Notonectidae & 60 & 0 & 6.5 & 25 & 73.5 & 0.8 & $3.7 b$ & 6.6 & 0.378 \\
\hline Euthyplociidae & 60 & 0 & 21.6 & 35 & 62 & 0.9 & $2.7 \mathrm{a}$ & 1.6 & 0.002 \\
\hline Hydropsychidae & 60 & 8.3 & 16.5 & 25 & 55 & 0.9 & $2.5 b$ & 2.6 & 0.072 \\
\hline
\end{tabular}

${ }^{*}$ E.I (\%) - Emergency Inhibition; letters do not differ from each other considering $p \leq 0.05 ; F=4.0098 ; G L=11 ; A N O V A: p=0.0031$. 


\section{Bioassay partial-field}

The effect of diflubenzuron on Euthyplociidae (Ephemeroptera) and Notonectidae (Hemiptera) started in the 48-hour post-application interval, and in Chironomidae (Diptera) and Hydropsychidae (Trichoptera), the mortality rate (\%) of the individuals submitted to semi-field bioassays. from $24 \mathrm{~h}$ post-application. All groups analyzed had a mortality rate of $>50 \%$ in the $96 \mathrm{~h}$ interval and the regression analysis revealed a strong relationship between the exposure time and the mortality rate (\%) of the individuals for all groups analyzed. The most sensitive group during the 4-day interval was Chironomidae (Diptera), with more than 70\% mortality, starting $24 \mathrm{~h}$ after application of diflubenzuron (Table I).

The regression analysis evaluating exposure time and mortality rate (\%) of individuals revealed a strong relationship between these variables for Hydropsychidae $\left(r^{2}=0.9\right)$, Notonectidae $\left(r^{2}=0.8\right)$, Euthyplociidae $\left(r^{2}=0.9\right)$ and Chironomidae $\left(r^{2}=0.9\right)$. The highest average emergence inhibition was observed in Notonectidae (3.7\%) and the lowest in Hydropsychidae (2.5\%). Generally, the inhibition values were estimated with about $1 \%$ between the maximum and minimum value found. However, analysis of the emergence inhibition data revealed a significant difference between the groups submitted to bioassays of diflubenzuron in partial-field. Individuals in the Euthyplociidae family showed significant differences when compared to other families, which presented similar responses to each other (Tukey 5\%) (Table I).

\section{Field application}

We collected a total of 1.102 insects specimens associated with the Anopheles sp. in the brick factory pits, distributed in six orders and 20 families. Hemiptera and Diptera were the most abundant orders, representing a little over 50\% of all the insects collected, the least abundant was Trichoptera (4\%). Among the insect families, Corixidae (21\%) was the most abundant and the least abundant were Nepidae (0.05\%) and Leptophlebiidae (0.05\%) (Table II).

The total Shannon diversity $\left(H^{\prime}\right)$ and richness (J 1st) of the brick factory pits was slightly higher in the pre-application reading than the post-application reading. The diversity of total Shannon pre-application was from $\mathrm{H}^{\prime}=0.94$ and post-application $H^{\prime}=1.0033$. The richness of total Jackniffe (J) pre-application was J=15 and postapplication J=19. However, the T-test revealed that there was no difference in diversity and richness between pre-and post-application ( $p=0.32)$ in the 15-day interval.

The dominant trophic feeding group in these breeding sites were predators, consisting of more than half of the all insects, followed by collectors (Table II). The structure of the insect community according to the functional trophic group pre- and post-application presented differences, with an increase in predators and reduction of other groups (Figure 2).

The physical and chemical characteristics of water in the brick factory pits are typical of isolated environments, i.e. no connection to another water body and exposed to the sun. The temperature of the water varied between $34.7^{\circ} \mathrm{C}$ and $37.7^{\circ} \mathrm{C}$, the $\mathrm{PH}$ between 5.2 and 7.1 , and the conductivity between 5.5 and $11.1 \mu \mathrm{S} / \mathrm{cm}$ (Figure 3). Comparisons of limnological variables showed no differences $(p>0.05)$ between the parameters observed ( $\mathrm{pH}$, conductivity, and temperature).

\section{DISCUSSION}

The data obtained from the laboratory bioassays indicated an immediate effect of diflubenzuron $24 \mathrm{~h}$ after application. In addition, the mortality rate (\%) was elevated during the first four days, with a peak at $96 \mathrm{~h}$ post-application, which was 
observed for both groups tested, eliminating about $100 \%$ of Buenoa until this interval (Table 1). These findings corroborate with results found by Msangi et al. (2011), who analyzed the effect of diflubenzuron on Culex and observed immediate effects on the immature mosquito, suggesting toxicity of diflubenzuron through direct contact.

We also observed that the elevated concentrations of diflubenzuron presented the highest mortality rate values (\%) of the groups tested, indicating a relationship between dose and response (Table I). This data corroborates with that found by Chen et al. (2008), who evaluated the effectiveness of two diflubenzuron concentrations on Aedes aegypti and noted that the higher the dosage, the more efficient the insecticide was on this mosquito species.

Considering the mortality rate (\%) observed for Chironomus, the dosage recommended by the manufacturer $(250 \mathrm{mg} / \mathrm{L})$ eliminated about $76 \%$ of individuals in aquariums, indicating sensitivity of these specimens to diflubenzuron. The effect of this larvicide on Chironomidae has already been reported by Ali \& Mulla (1977), who verified $96 \%$ reduction in populations of Chironomus utahensis Malloch, 1915 and 91100\% for Procladius (Diptera: Chironomidae), in large artificial lakes in Florida, where these insects are considered pests, and are a nuisance to the human population. Our data agrees with by Steelman et al. (1975), who observed a significant reduction of Chironomidae in the field during a control campaign of Psorophora columbie (Dyar \& Knab). Later, Ali \& Lord (1980) observed the sensitivity of Chironomidae in the field during experiments in small artificial lakes and found a $98 \%$ reduction in chironomids six days after application.

In a natural environment the significant reduction in chironomids negatively affects the whole community of aquatic insects and fish since these animals are a base group in the food chain for many other organisms. According to Hansen \& Garton (1982), the effectiveness of diflubenzuron is influenced by the generation time of the different groups of aquatic insects, which causes differences in their sensitivity. Therefore, since chironomids have similar generation times as Culicidae, diflubenzuron acts more effectively, eliminating chironomids from the environment in a short period of time.

In partial-field conditions, we found higher mortality rates (\%) during the first four days of exposure and after the 5th day no mortality was observed for the organisms tested (Table I). Such fact may be associated with the location where the experiment was assembled, consisting of a shaded area without direct sun rays, which promotes greater permanence of this larvicide in the environment. According to Chen et al. (2008), the residual power of diflubenzuron can be long, up to eight weeks post-application of high doses $(100 \mathrm{~g} / \mathrm{ha})$ in Aedes aegypti breeding sites. The breeding sites of these mosquitoes are small containers with water, which are protected from sun and rain. Therefore, the persistence of diflubenzuron in an environment seems to be higher in areas with low incidence of solar rays.

The specimens of Notonectidae, Hydropsychidae, and Chironomidae presented similar responses for emergence inhibition, and Euthyplociidae (Ephemeroptera) was the most sensitive to the larvicide, considering all the groups tested (Table I). These data agree with Farlow et al. (1978), Hurd et al. (1996) and Mulla et al. (1986), who analyzed the effect of diflubenzuron in the field and found that Ephemeroptera was one of the most sensitive groups in the application. This group is admittedly sensitive to environmental changes and it is often used as a clean water bioindicator, which explains its high sensitivity to diflubenzuron.

Thestructure of the aquaticinsectcommunity in Anopheles breeding sites is characteristic of 
aquatic environments with low rates of dissolved oxygen and high sun exposure. The families Chironomidae and Corixidae were dominant in the sampled brick factory pits. According to Devái (1990), chironomids are dominant in most continental aquatic ecosystems, tolerant to a certain degree of hypoxia, and are treated as an indispensable component of the food chain in the aquatic ecosystem. Studies conducted by Wollmann (2000) indicate that the high density of Corixidae may be related to low $\mathrm{pH}$ values, i.e. acidic waters. Of the ten brick factory pits studied, only one presented average $\mathrm{pH}$ values > 7 , this may have influenced the establishment of a large Corixidae population (Table II).

The richness and diversity data of the associated insect fauna with Anopheles in the field presented no significant differences in the pre-and post-application of diflubenzuron during the 15-day interval. Such data corroborates with Wandscheer et al. (2017), who evaluated the richness and diversity of aquatic macroinvertebrates exposed to fungicides and insecticides and found no significant impacts caused by the application of diflubenzuron in a 30-day period.

These results are also similar to those found by Farlow et al. (1978) during a mosquito control campaign in a marshy area in the state of Louisiana (USA). They analyzed the population of non-target organisms exposed to diflubenzuron and observed no significant difference between the populations after six applications over an 18-month period.

The average values of diversity $\left(H^{\prime}\right)$ for aquatic insects found in the brick factory pits were close to those found by Ferreira et al. (2015), who studied the effect of Bacillus sphaericus on Anopheles and associated insect fauna with fish farming ponds in the Central Amazon. However, the richness of aquatic insects in fish farming ponds was higher when compared to the brick factory pits.

In the present study, the dose of diflubenzuron did not significantly impact the associated insect fauna with Anopheles in the field during the 15-day period, though, future studies with longer observation times are necessary. However, other studies have found reduced diversity for insects exposed to diflubenzuron. Such reduction was observed in the laboratory by Hansen \& Garton (1982), where they simulated a complex interaction network including fungi, bacteria, oligochaetes, and aquatic insects.

The proportion of functional trophic groups in the pre and post-application samples suggests less predators and more organisms from other groups (Figure 2). However, previous studies show that predators do not have high sensitivity to diflubenzuron concentrations used to control Diptera, therefore, we cannot support that this reduction was the result of diflubenzuron application in the environment (Balog et al. 2011).

The temperature of the brick factory pits ranged from $35^{\circ} \mathrm{C}$ to $40^{\circ} \mathrm{C}$, which is typical for aquatic environments completely exposed to the sun (Figure 3). The physical and chemical parameters of the water presented acidic $\mathrm{pH}$ and electrical conductivity values typical for aquatic environments with influence of darker waters from the Rio Negro, according to Junk (1983).

The data obtained in this study suggest that diflubenzuron could act by direct contact, causing the death of individuals before acting on the biosynthesis of chitin, within the first four days of exposure, which we observed both in the laboratory and in partial- field conditions. All groups submitted to bioassays were sensitive to high doses of diflubenzuron and presented similar responses of emergence inhibition, except for Euthyplociidae which proved to 
be highly sensitive. The bioassays in the field revealed no significant differences between pre and post application samples in the 15-day period. Such data suggests rapid degradation of diflubenzuron in the environment when applied in places that are completely exposed to solar rays. However, the results obtained from the bioassays indicate that diflubenzuron is not selective and if applied in high doses presents toxicity, compromising the survival of other aquatic associated insect fauna with Anopheles.

Table II. Relative abundance (R.A \%) of associated insect fauna with Anopheles sp. during the field experiment with diflubenzuron in clay pits, Iranduba, Amazonas.

\begin{tabular}{|c|c|c|c|c|c|c|}
\hline Taxon & Family & Functional feeding & Pre & Post & $\mathbf{n}$ & R. $A^{*}(\%)$ \\
\hline \multirow[t]{5}{*}{ Hemiptera } & Belostomatidae & Predators & 19 & 6 & 25 & 2 \\
\hline & Corixidae & Predators & 20 & 217 & 237 & 21.5 \\
\hline & Gerridae & Predators & 1 & 1 & 2 & 0.2 \\
\hline & Nepidae & Predators & 1 & 0 & 1 & 0.05 \\
\hline & Notonectidae & Predators & 14 & 29 & 43 & 4 \\
\hline \multirow[t]{3}{*}{ Odonata } & Coenagrionidae & Predators & 32 & 23 & 55 & 5 \\
\hline & Libellulidae & Predators & 50 & 70 & 120 & 11 \\
\hline & Aeshnidae & Predators & 5 & 0 & 5 & 0.4 \\
\hline \multirow[t]{3}{*}{ Ephemeroptera } & Caenidae & Collectors & 102 & 55 & 157 & 14 \\
\hline & Baetidae & Scrapers & 2 & 10 & 12 & 1 \\
\hline & Leptophlebiidae & Collectors & 1 & 0 & 1 & 0.05 \\
\hline Trichoptera & Hydroptilidae & Scrapers & 28 & 18 & 46 & 4 \\
\hline \multirow[t]{4}{*}{ Coleoptera } & Hydrophilidae & Collectors & 43 & 50 & 93 & 8.3 \\
\hline & Dytiscidae & Predators & 4 & 1 & 5 & 0.4 \\
\hline & Gyrinidae & Predators & 4 & 1 & 5 & 0.4 \\
\hline & Noteridae & Predators & 2 & 0 & 2 & 0.2 \\
\hline \multirow[t]{4}{*}{ Diptera } & Chironomidae & Collectors & 112 & 36 & 148 & 13.5 \\
\hline & Culicidae & Generalists & 46 & 32 & 78 & 7 \\
\hline & Chaoboridae & Predators & 3 & 32 & 35 & 3.5 \\
\hline & Ceratopogonidae & Predators & 10 & 22 & 32 & 3.5 \\
\hline Total & 20 & 4 & 499 & 603 & 1102 & 100 \\
\hline
\end{tabular}

*R.A - Relative Abundance.
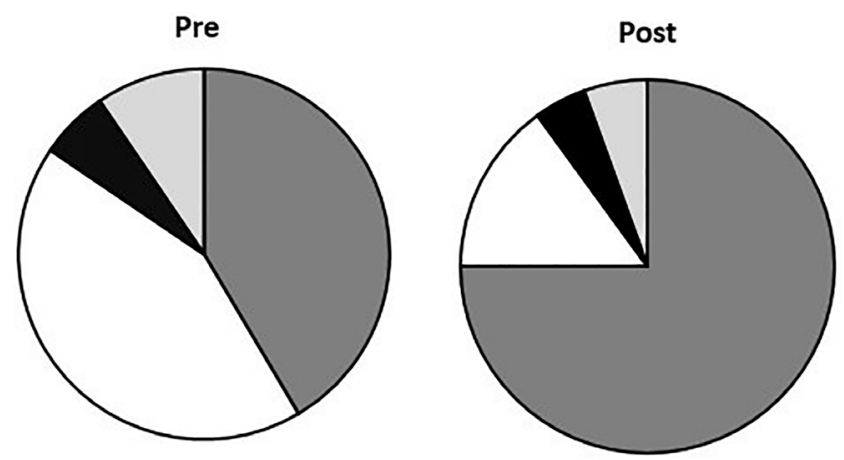

Figure 2. Functional trophic groups (\%) found in the brick factory pits during the pre- and post-application of diflubenzuron. 


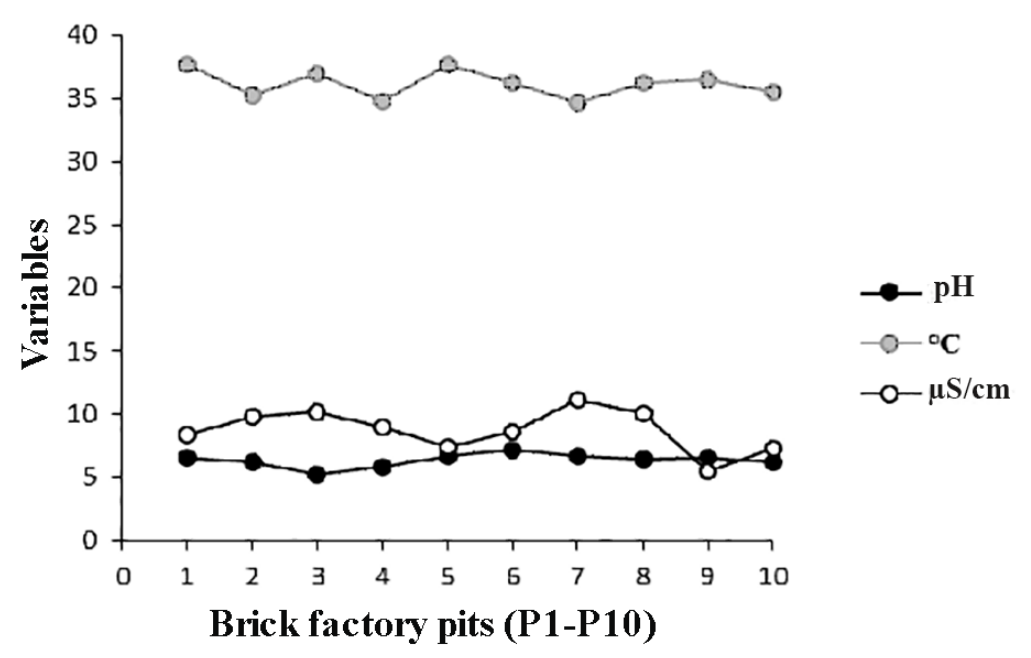

Figure 3. Physical and chemical parameters of pre-application in the clay pits (P1-P10), Km 2 at the AM 070, Iranduba, Amazonas.

\section{Acknowledgments}

The authors appreciate the financial support from the Conselho Nacional de Desenvolvimento Científico e Tecnológico - CNPq, Fundação de Amparo a Pesquisa do Estado do Amazonas - FAPEAM, Brazil and Coordenação de Aperfeiçoamento de Pessoal de Nivel Superior CAPES, Brazil/Code 001.

\section{REFERENCES}

AL-SHAMI AS, HEINO J, SALMAH MRC \& MADRUS MR. 2013. Drivers of beta diversity of macroinvertebrate communities in tropical forest streams. Freshw Biol 58: 1126-1137.

AL-SHAMI SA, RAWI CSM, AHMAD AH, MADRUS MR \& MUTAIRI K. 2014. Importance of regional diversity and environmental conditions on local species richness of aquatic macroinvertebrates in tropical forested streams. J Trop Ecol 30(4): 335-346.

ALBERTONI EF \& PALMA-SILVA C. 2010. Caracterização e importância dos invertebrados de águas continentais com ênfase nos ambientes de Rio Grande. Cad Eco Aquática 5(1): 9-27.

ALI A \& LORD J. 1980. Experimental insect growth regulators against some nuisance chironomid midges of central Florida. J Econ Entomol 73(2): 243-249.

ALI A \& MULLA MS. 1977. The IGR diflubenzuron and organophosphorus insecticides against nuisance midges in man-made residential-recreational lakes. J Econ Entomol 70: 571-577.
ARCOS AN, FERREIRA FAS, CUNHA HB \& TADEI WP. 2018. Characterization of artificial larval habitats of Anopheles darlingi (Diptera: Culicidae) in the Brazilian Central Amazon. Rev Bras de Entomol 62: 267-274.

AYRES-PERES L, SOKOLOWICZ CC \& SANTOS S. 2006. Diversity and abundance of the benthic macrofauna in lotic environments from the central region od Rio Grande do Sul State, Brazil. Biota Neotrop 6(3): 1-10.

BALOG A, FERENCZ L \& HARTEL T. 2011. Effects of chitin and contact insecticide complexes on rove beetles in comercial orchards. J Insect Sci 11: 10 p.

BELLINATO DF, VIANA-MEDEIROS PF, ARAÚJO SC, MARTINS AJ, LIMA JBP \& VALLE D. 2016. Resistance status to the insecticides Temephos, Deltamethrin, and Diflubenzuron in Brazilian Aedes aegypti populations. BioMed Res Internat 2016: $12 \mathrm{p}$.

BORGES RA, ARRUDA W, FERNANDES O, CAVASIN GM, GARCIA DA SILVA HH \& GARCIA DA SILVA I. 2012. Mecanismos de ação larvicida do diflubenzuron sobre Aedes aegypti evidenciados pelas alterações ultraestruturais. Rev Patol Trop 4: 222-232.

BORROR DJ \& DELONG DM. 2011. Introdução ao Estudo dos Insetos. Ed. Cengage Learning.

BRAGA IA \& VALLE D. 2007. Aedes aegypti: inseticidas, mecanismos de ação e resistência. Epidemiol Serv Saúde 16(4): 279-293.

CALLISTO M \& GONÇALVES JR JF. 2005. Bioindicadores Bentônicos. In: Fábio Roland, Dionéia César e Marcelo Marinho (Eds). Lições de Limnologia, p. 371-379. [A review of bottom fauna as bioindicators in Brazilian freshwaters]. 
COSTA FM \& TADEI WP. 2011. Laboratory toxicity evolution of Diflubenzuron, a chitin-synthesis inhibitor, against Anopheles darlingi (Diptera: Culicidae). J Res Biology 1(6): 444-450.

COSTA FM \& TADEI WP. 2012. Morphological alterations caused by Diflubenzuron in Anopheles darlingi Root (Diptera: Culicidae). J Res Biology 2(3): 215-221.

CUMMINS KW. 2016. Combining taxonomy and function in the study of stream macroinvertebrates. J Limnol 75: 235-241.

CHEN CD, SELEENA B, ChIANG YF \& LEE HL. 2008. Field evaluation of the bioefficacy of diflubenzuron (Dimilin ${ }^{\circledR}$ ) against container-breeding Aedes sp. mosquitoes. Trop Biomedicine 25(1): 80-86.

COHEN E. 2001. Chitin synthesis and inhibition: a revisit. Pest Manag Sci 57: 946-950.

DEVÁl G. 1990. Ecological background and importance of the change of Chironomid fauna in shallow Lake Balaton. Hidrobiol 321: 17-28.

DULMAGE HT, YOUSTEN AA, SINGER S \& LACEY L. 1990. Guidelines for production of Bacillus thuringiensis/ $\mathrm{H}-14$ and Bacillus sphaericus. UNDP/World Bank/WHO, St Comm Biol Control of Vectors, Geneva, 59 p.

FARLOW JE, BREAUD TP, STEELMAN CD \& SCHILLING PE. 1978. Effects of the insect growth regulator diflubenzuron on nontarget aquatic populations in a Louisiana intermediate marsh. Environ Entomol 7: 199-204.

FERREIRA FAS, ARCOS AN, SAMPAIO RTM, BRANDÃO IR \& TADEI WP. 2015. Effects of Bacillus sphaericus Neide on Anopheles (Diptera: Culicidae) and associated insect fauna in fish ponds in the Amazon. Rev Bras Entomol 59(3): 234-239.

FLACIO E, ENGELER L, TONOLLA M, LÜTHY P \& PATOCCHI N. 2015. Strategies of a thirteen-year surveillance programme on Aedes albopictus (Stegomyia albopicta) in Southern Switzerland. Parasit Vectors 8: 208.

FORATTINI OP. 2002. Culicidologia médica. São Paulo: EDUSP. V. 2

HANSON SR \& GARTON RR. 1982. The effects of diflubenzuron on a complex laboratory stream community. Arch Environ Contam Toxicol 11: 1-10.

HEMINGWAY J, HAWKES NJ, MCCARROLL L \& RANSON H. 2004. The molecular basis of insecticides resistance in mosquitoes. Insect Biochem Mol Biol 34: 653-665.

HURD MK, PERRY SA \& PERRY WB. 1996. Nontarget Effects of a Test Application of Diflubenzuron to the Forest Canopy on Stream Macroinvertebrates. Environ Toxicol Chem 15(8): 1344-1351.
JUNK WJ. 1983. As águas da região Amazônica. In: Salati Eneas et al. Amazônia: desenvolvimento, integração e ecologia. São Paulo: Brasiliense, p. 54-55.

LEORA SOFTWARE. 1987. POLO-PC: user's guide to Probit or Logit analysis. LeOra Software, Berkeley, Calif.

LOBO KS, SOARES-DA-SILVA J, SILVA MC, TADEI WP, POLANCZYK RA \& PINHEIRO VCS. 2018. Isolation and molecular characterization of Bacillus thuringiensis found in soils of the Cerrado region of Brazil, and their toxicity to Aedes aegypti larvae. Rev Bras Entomol 62: 5-12.

LÓPEZ RUF ML, MAZZUCCONI AS \& BACHMANN AO. 2003. Heteróptera acuáticos y Semiacuáticos del Parque Nacional Mburucuyá (Provincia de Corrientes, Argentina). Rev Soc Entomol Argent 62(1-2): 65-71.

LYRA JRM, FERRAZ JMG \& SILVAAPP. 1998. Acción de inhibidores de la sintesis de La quitina en la reprodución de Spodoptera littoralis (Boisd.) (Lepidoptera: Noctuidae). An Soc Entomol Brasil 27: 569-576.

MACHADO AA, COLEONE AN, ABE FR, AMÉRICO JHP, LIMA JBP \& NETO JGM. 2015. The efficacy of Diflubenzuron for the control of larvae from two populations of Aedes aegypti with different susceptibility levels to Temephos, under laboratory conditions. J Health Biol Sci 3(1): 25-29.

MARTINS F \& DA SILVA IG. 2004. Evaluation of the inhibiting activity of the diflubenzuron on the ecdysis of larvae of Aedes aegypti (Linnaeus, 1762) (Diptera, Culicidae). Rev Soc Bras Med Trop 37(2): 43-56.

MARTINS RT, OLIVEIRA VC \& SALCEDO AKM. 2014. USO doS insetos aquáticos na avaliação de impactos antrópicos em ecossistemas aquáticos. In: Insetos aquáticos na Amazônia brasileira: taxonomia, biologia e ecologia. Hamada N, Nessimian JL and Querino RB. Editora do INPA, $728 \mathrm{p}$.

MCCAFFERTY WP. 1981. Aquatic Entomology. The Fishermens and Ecologists Illustrated guide to Insects and their Relatives. Jones and Bartlett Publishers, Inc. Portolla Valley, Boston, $448 \mathrm{p}$.

MERRITT RW, CUMMINS KW \& BERG MB. 2008. An introduction to the aquatic macroinvertebrates of North America, 4th ed., Kendall-Hunt Publishing Company, 1158 p.

MERZENDORFER H. 2006. Insect chitin synthases: a review. J Comp Physiol 176: 1-15.

MERZENDORFER H \& ZIMOCH L. 2003. Chitin metabolism in insects: structure, function and regulation od chitin synthases and chitinases. J Exp Biol 206: 4393-4412.

MSANGI S, LYATUU E \& KAWEKA J. 2011. Field and laboratory evoluation of bioefficacy of an insect growth regulator 
(Dimilin) as a larvicida against mosquito and housefly larvae. J Trop Med 2011: 1-8.

MULLA MS. 1979. New insect growth regulators against flood and stagnat water mosquitoes-effects on non target organisms. Mosq News 39: 746-755.

MULLA MS. 1995. The future of insect growth regulators in vector control. J Am Mosq Control Assoc 11(2): 269-273.

MULLA MS \& DARWAZEH HA. 1975. Evaluation of insect growth regulators against chironomids in experimental ponds. Proc Pap Calif Mosq Control Assoc 49: 164-168.

MULLA MS \& DARWAZEH HA. 1979. New insect growth regulators against flood and stagnant water mosquitoeseffects on no target organisms. Mosq News 39 (4): 746-755.

MULLA MS, DARWAZEH HA, KENNEDY B \& DAWSON DM. 1986. Evaluation of new insect growth regulators against mosquitoes with notes on nontarget organisms. J Am Mosq Control Assoc 2(3): 314-320.

ROCHA HDR, PAIVA MHS, SILVA MS, ARAÚJO AP, CAMACHO DRRA, MOURA AJF, GÓMEZ LF, AYRES CFJ \& SANTOS MAVM. 2015. Susceptibility profile of Aedes aegypti from Santiago Island, Cabo Verde, to insecticides. Acta Trop 152: 66-73.

RODRIGUES IB, TADEI WP, DIAS JMCS \& LIMA CA. 2013. Atividade larvicida de Bacillus sphaericus 2362 contra Anopheles sp. (Diptera: Culicidae) em rios do Amazonas, Brasil. Bioassay 8: 2.

RODRIGUES WC. 2018. DivEs - Diversidade de Espécies Software e Guia do Usuário, v.4.4.8, 2018. Disponível em: http://dives.ebras.bio.br.

ROSENBERG DM \& RESH VH. 1993. Introduction to freshwater biomonitoring and benthic macroinvertebrates, $\mathrm{p}$. 1-9. In: Rosenberg DM and Resh VH (Eds), Freshwater biomonitoring and benthic macroinvertebrates. Chapman \& Hall, New York, 488 p.

SADANANDANE C, BOOPATHI DOSS PS \& JAMBULINGAM P. 2012. Efficacy of three formulations of diflubenzuron, an insect growth regulator, against Culex quinquefasciatus Say, the vector of Bancroftian filariasis in India. Indian J Med Res 136 (5): 783-791.

SOARES-DA-SILVA J, PINHEIRO VCS, LITAIFF-ABREU E, POLANCZYK RA \& TADEI WP. 2015. Isolation of Bacillus thuringiensis from the state of Amazonas, in Brazil, and screening against Aedes aegypti (Diptera, Culicidae). Rev Bras Entomol 59: 1-6.

STEELMAN CD, FARLOW JE, BREAUD TP \& SCHILLING PE. 1975. Effects of growth regulators on Psorophora columbiae (Dyar and Knab) and nontarget aquatic insect species in rice fields. Mosq News 35(1): 67-76.
TADEI WP, RODRIGUES IB, RAFAEL MS, SAMPAIO RTM, MESQUITA HG, PINHEIRO VCS, ZEQUI JAC, ROQUE RA \& SANTOS JMM. 2017. Adaptative processes, control measures, genetic background, and resilience of malaria vectors and environmental changes in the Amazon region. Hydrobiol 789: 179-196.

TRIVINHO-STRIXINO S \& STRIXINO G. 1995. Larvas de Chironomidae (Diptera) do Estado de São Paulo: Guia de identificação e diagnose dos gêneros. São Carlos: Pograma de Pós-graduação da Universidade Federal de São Carlos, São Carlos, 229 p.

WANDSCHEER ACD, MARCHESAN E, SANTOS S, ZANELLA R, SILVA MF, LONDERO GP \& DONATO G. 2017. Richness and density of aquatic benthic macroinvertebrates after exposure to fungicides and insecticides in rice paddy fields. An Acad Bras Cienc 89: 355-369.

WHO - WORLD HEALTH ORGANIZATION. 2006. Pesticides and their application. For the control of vectors and pests of public health importance. $6^{\text {th }}$ ed., Geneva.

WHO - WORLD HEALTH ORGANIZATION. 2007. Guidelines for drinking-water quality [electronic resource]: incorporating first addendum. $3^{\text {rd }}$ ed., vol. 1, Recommendations.

WILKE ABB, GOMES AC, NATAL D \& MARRELLI MT. 2009. Controle de vetores utilizando mosquitos geneticamente modificados. Rev Saúde Pública 43(5): s869-874.

WOLLMANN K. 2000. Corixidae (Hemiptera, Heteroptera) in acidic mining lakes with $\mathrm{pH}<3$ in Lusatia, Germany. Hydrobiol 433(1-3): 181-183.

ZAHRAN HEM, KAWANNA MA \& BOSLY HA. 2013. Larvicidal Activity and Joint Action Toxicity of Certain Combating Agents on Culex pipiens L. Moquitoes. Ann Rev Res Biol 3(4): 1055-1065.

ZHU KY, STEPHANI H, ZHANG J, ANDERSON TD \& STARKEY SR. 2007. Comparative Sudies on Effects of three chitin synthesis inhibitors on common Malaria mosquito (Diptera: Culicidae). J Med Entomol 44(6): 1047-1053.

\section{How to cite}

FERREIRA FAS, ARCOS AN, MAIA NSG, SAMPAIO RTM, COSTA FM, RODRIGUES IB \& TADEI WP. 2020. Effects of diflubenzuron on associated insect fauna with Anopheles (Diptera: Culicidae) in laboratory, partial-field, and field conditions in the Central Amazon. An Acad Bras Cienc 92: e20180590. DOI 10.1590/0001-3765202020180590.

Manuscript received on June 11, 2018; accepted for publication on February 20, 2019 
FRANCISCO A.S. FERREIRA ${ }^{1}$

https://orcid.org/0000-0002-5128-7457

\section{ADRIANO N. ARCOS}

https://orcid.org/0000-0002-9509-3283

NATALIELLI S.G. MAIA

https://orcid.org/0000-0003-0603-5645

RAQUEL T.M. SAMPAIO ${ }^{4}$

https://orcid.org/0000-0002-3026-2568

FÁBIO M. COSTA

https://orcid.org/0000-0002-1237-4558

\section{ILÉA B. RODRIGUES ${ }^{4}$}

https://orcid.org/0000-0002-1505-9959

\section{WANDERLI P. TADEI}

https://orcid.org/0000-0002-0612-3285

${ }^{1}$ Programa de Pós-Graduação em Entomologia, Instituto Nacional de Pesquisas da Amazônia / INPA, Avenida André Araújo, 2936, Aleixo, 69011-970 Manaus, AM, Brazill

${ }^{2}$ Programa de Pós-Graduação em Ecologia e Conservação, Universidade Federal de Mato Grosso do Sul/UFMS, Av. Costa e Silva, s/n, Universitário, 79070-900 Campo Grande, MS, Brazil

${ }^{3}$ Programa de Pós-Graduação em Ensino de Ciências e Matemática, Universidade Federal do Amazonas/ UFAM, Avenida General Rodrigo Octavio Jordão Ramos, Coroado I, 1200, 69067-005 Manaus, AM, Brazil ${ }^{4}$ Laboratório de Malária e Dengue, Instituto Nacional de Pesquisas da Amazônia/INPA, Avenida André Araújo, Aleixo, 69011-970 Manaus, AM, Brazill

Correspondence to: Francisco Augusto da Silva Ferreira E-mail:fcoaugusto.bio@gmail.com

\section{Author Contributions}

Francisco A. S. Ferreira, Natalielli S. G. Maia and Raquel T. M. Sampaio conducted the field, partial-field and laboratory studies and drafted the manuscript. Adriano N. Arcos and Fábio M. Costa helped to analyzed the data and drafted the manuscript. Iléa B. Rodrigues and Wanderli P. Tadei helped to conduct field studies and gave critical feedback to the manuscript. All authors have approved the final article.

\section{(cc) BY}

